\title{
Alternative Models in Mangrove Management based Ecopreneurship in Preserving the Mangrove Forests
}

\author{
Risma Haris \\ Universitas Negeri Makassar \\ Makassar, Indonesia
}

\author{
Andi Muh. Taufik Ali \\ Universitas Negeri Makassar \\ Makassar, Indonesia
}

\author{
Andi Farida Arsal \\ Universitas Negeri Makassar \\ Makassar, Indonesia
}

\begin{abstract}
Research is done in the area of the nature reserve Bay of Apar, Tanjung Harapan, district Paser, East Kalimantan. The purpose of this research is to design an alternative model of the management of mangrove based - Ecopreneurship that suitable for the fishpond farmers in the area of the nature reserve Bay of Apar in preserving the mangrove forests. The subject of the research was the fishpond farmers in the area of the nature reserve Bay of Apar, data retrieval is done by the method of purposive sampling. The data collected in the study consists of two parts: primary data in the form of a map of Citralandsat in the area of the nature reserve Bay of Apar and the secondary data is done by the method of observation, interviews, and documentation. From the results of the analysis of the interpretation of the Image using a lansat GIS (geographic information system), it is known that the conversion of mangroves into fishponds has been increasing from year to year the impact of the damage on the function of mangrove forests and it is very dependent on mangrove forests ranging from the opening of the fishpond, settlements, entrepreneurship and the fulfilment of the needs of the day today. From the results of the research is desire need of mangrove management that is optimal for the fishpond farmers in conserving the mangroves while entrepreneurship fisheries to meet the needs of his life. I found that the model silvofishery empang trench is perfect is applied in the area of the nature reserve Bay of Apar as alternative model in the management of mangrove based - Ecopreneurship.
\end{abstract}

Keywords-mangrove management; ecopreneurship; preserving

\section{INTRODUCTION}

In Indonesia, mangrove area is growing in the coastal areas around 257 local government of the 33 provinces. Directorate General of Land Rehabilitation and Social Forestry (Dirjen RLPS), the Ministry of Forestry reported that in 2008, extensive mangrove forests of Indonesia (inside and outside forest areas) is estimated to be approximately 6.89 billion ha.

Mangrove Forests have an important role to the survival of the human race because of mangrove forests has multiple roles, also, serves to maintain the sustainability of forest ecosystems and coastal waters, as well as provide direct benefits to the economic prosperity of the community around it. However, in fact the monetary crisis that has ever occurred in Indonesia in 1997, leaving the issue of degradation of the mangrove forests in the area of the conservation of the nature reserve Bay of Apar, over the function of mangrove forests due to uncontrolled economic communities and heeding the important role of mangrove forests as green belt. Since 20 years in some areas in East Kalimantan has felt the negative impact of environmental crises and environmental degradation.

The condition of the environment around the area of the nature reserve of Mangrove Forests at this time changes mainly to become fishpond acreage and settlements. High rates of degradation of mangrove forests are not balanced with conservation of the ecosystem [1]. Great social conflict in which indigenous peoples are residing for a long time that cannot be avoided. Anticipating the social inequality is currently developing a pattern of mangrove ecosystem management oversight involving the community, but still can be one of livelihood or entrepreneurship for the surrounding communities.

The community tried to submit a research proposal by creating Alternative models of management of mangrove which are suitable for the fishpond farmers -based the Ecopreneurship with focus area is the area of the nature reserve Bay of Apar.

\section{RESEARCH METHODS}

The data collected in this study consists of two parts: primary data in the form of a map of Citra Landsat in the area of the nature reserve Bay of Apar and the secondary data is done by the method of observation, interviews, and documentation as well as the data obtained from the local community and Conservation of Natural Resources in East Kalimantan Region III.

Data collection that includes tabular data and analog data. The analog data that is collect in the form of Citra Landsat and other thematic maps is needed. Whereas tabular data is statistical data from the area. At this stage all data for conversion into digital form to be present in the information database (Geographic Information System) GIS [2]. As it known that in this type of research data are grouped in two groups of data types are:

- Spatial data that includes a data administration area, streams, roads, villages, and other land use. 
- Spatial data in the form of data population, types of vegetation and others-others to explain spatial data associated.

Data-data that has been collected, carried out the management of its data in descriptive qualitative, that is present in the form of writings by developing various thoughts and ideas as well as based on the theory of the literature and available and adapted to the purpose of the research. This research focuses on the systematic explanation of the facts obtained while doing research [3].

Citra Landsat interpretation aimed at reviewing the image with the intention of identifying objects that reside on the surface of the Earth that reflect on the image that produces a form of the vector-shaped data point, line, and polygon. The process of interpretation done by restricting the areas which have the characteristic elements of different interpretations. This indicates the existence of a type of use or the closure of the land. The withdrawal limit use or land closure is done directly through the process of digital screen [4].

This process produces a map of use/land closure. The second process is done with the help of software ArcView 3.3 with the extension ArcView Image Analysis 1.1.

In the interpretation of imagery performed several stages: (a) Pretreatment data digital; (b) Sharpening the image (image enhancement); (c) Classification the image (the image classification toolbar); (d) Test accuracy; (e) results of the interpretation of the image digitally.

\section{RESULTS AND DISCUSSION}

\section{A. Conditions of mangrove land and fishpond}

Based on a map of Mangrove and Data Dissemination in 2004 until 2008 mentioned the extensive damage the mangroves in the Bay nature reserve area the Apar have elevated, before the opening of the new fishpond prohibition.

Damage caused due to land use or land cover which is not by the allocation due to human intervention in its utilization. In a span of 5 years where the extensive mangrove of 17212.6 $\mathrm{Ha}$ reduced to $12308.43 \mathrm{Ha}$, which means the decline of mangrove area of 4904.17 or $10 \%$.

TABLE I. LAND AREA OF FISHPOND AND MANGROVE

\begin{tabular}{|c|c|c|}
\hline Year & Fishpond(ha) & Mangrove (ha) \\
\hline 2004 & 387,515 & $17.212,60$ \\
2008 & 5437,373 & $12.308,43$ \\
\hline \multicolumn{2}{|c|}{ The data source; Conservation Natural Resources }
\end{tabular}

Conservation Area III and Field Observation along coastal stretches of Fishpond to reach the hundreds of acres of mangrove area while remaining very less. The opening of the fishpond farmed was done in the traditional way using hot, even in modern by using excavators. In the village of Lori found some fishpond which is very near the coast, where the only remaining mangrove forest $5-10$ meters from the coastline. Where is the broad opening of 387,515 ha of ponds increased to $5,437,373$ ha, which means a significant increase of 5,049,858 ha. This resulted in a decline in quality as well as the quantity of mangrove forests.

\section{B. History of the fishpond farmers in the area of the nature reserve bay of apar}

Based on the interview results by the fishpond farmers in the Bay of Apar, that the demands of the economy were one factor causes the opening of the Fishpond in the area of the nature reserve. In the view of the majority of the population's livelihood Charts that were in the area of the nature reserve Bay of apar like fishing as a livelihood $(46,8 \%)$ and followed by the fishpond farmers $(27.6 \%)$. By looking at the type of capture tool and used boats, the fishermen can be said to be a small fishing/traditional with distance to sea \pm 4 nautical miles. Income from fishing is not too significant to raise economy a fishermen family; this causes the majority of fishers also conduct entrepreneurial field on fishpond.

The fishpond is declining each year. This condition is caused by the degradation of the coastal environment due to logging of mangrove to open acreage fishpond this shows that the interests of the inhabitants of the land against high enough to meet the needs of his life by the percentage of the population of more than $20 \%$ who rely on opening fishpond directly.

Chopra reveals that Ecopreneurship associated with an environmentally friendly way to do business [5]. There are three essential elements to achieve success in Ecopreneurship: (a) Eco - Innovation: this relates to providing innovative solutions to address environmental problems; (b) Eco - the commitment: this relates to creating and implementing policies that will help create commitment and focus on the activities of the green; (c) Eco - opportunity: this relates to identifying opportunities for innovation that will help to solve environmental problems and achieve sustainability in business.

Ecopreneurship also explains the important role ecopreneur in preserving the environment, including Earth, biodiversity, and ecosystem. And one of them is the degradation of natural resources becomes a major problem. Because Most natural resources are limited. So the researchers found that the concept of Ecopreneurship is very suitable with Model Silvofishery.

Silvofishery model is one of the mangrove rehabilitation models which involves the participation of the local community. Silvofishery model is a series of integrated activities between the maintenance, management, and preservation of mangrove forests with fish farming. Silvofishery, which in integrated activities between fisheries and aquaculture brackish mangrove forests in the same location [6].

From the results of this research, the fishpond Silvofishery is the perfect Trench Empang system allocated on the area of the nature reserve Bay of Apar, due to this condition can be applied to the area of the former pond which will be rehabilitated by utilizing part of the terrace pond (central part) for planting mangroves. 
C. Analysis of profits with environmental parameters on the concept ecopreneurship and model salvo fishery

As for the profits on environmental parameters are: (1) mangrove can absorb energy caused by hurricanes and cope with the ups and downs of seawater; (2) Able to absorb heavy metals such as $\mathrm{Fe}$ and $\mathrm{Cu}$; (3) Assimilate material waste derived from sea or land; (4) As a medium nitrogen turnover, where the $\mathrm{N}$ and $\mathrm{P}$ content of more $0.79 \mathrm{ppm}$ and $0.79 \mathrm{ppm}$; (5) As a natural supply of feed for fishpond, while production of larvae on a shrimp as a stock; (6) As the region's water supply source, and neutralization of waste for fishpond activities.

So far, conservation efforts and management is still far behind; still much to learn about the proper management and sustainable conservation of mangrove forests. The mangroves have an enormous ecological value. They protect and stabilize the coastline, coastal waters of enriching, commercial forest products and supporting coastal fisheries. The mangrove forest is the most productive ecosystems in the world, producing organic carbon far exceeds the requirements of ecosystems and contribute significantly to the global carbon cycle [7].

\section{CONCLUSION}

Based on the Data of Natural Resource Conservation Area III and Field Observation along the coastal village of fishponds which land stretches Lori reach hundreds of acres, while the remaining mangrove area is very less. Where is the broad opening of 387,515 ha of fishpond increased to $5,437,373$ ha, which means a significant increase of 5,049,858 ha. This resulted in a decline in quality as well as the quantity of mangrove forests.
In the past five years, extensive mangrove forests of 17212.6 ha reduced to 12308.43 ha, which means the decline of mangrove area of 4904.17 ha.

Researchers found that the concept of Ecopreneurship very appropriate with the Model Silvofishery. Silvofishery model is one of the mangrove rehabilitation models which involves the participation of the local community. Silvofishery model is a series of integrated activities between the maintenance, management, and preservation of mangrove forests with fish farming.

\section{References}

[1] L. Nurrani, M. Bismark, and S. Tabba, "Institution and Communities Participation in the Conservation Of Mangrove/Case Study in Tiwoho Village, North Province," J. Wasian, vol. 2, 2015.

[2] P. A. Burrough, R. McDonnell, R. A. McDonnell, and C. D. Lloyd, Principles of geographical information systems. Oxford University Press, 2015.

[3] S. L. Jackson, Research methods and statistics: A critical thinking approach. Cengage Learning, 2015.

[4] Y. Lisnawati and A. Wibowo, "The Use of Landsat ETM + Images for Monitoring Landuse Changes in Puncak Area, West Java,” J. Penelit. Hutan Tanam., vol. 4, no. 2, pp. 79-90, 2007.

[5] K. Chopra, "Ecopreneurship: Is it a viable business model," AE Int. J. Multidiscip. Res., vol. 2, no. 3, pp. 1-6, 2014.

[6] R. Budihastuti, S. Anggoro, and S. W. Saputra, "The Application of Silvofishery on Tilapia (Oreochromis niloticus) and Milkfish (Chanos chanos) Fattening Within Mangrove Ecosystem of the Northern Coastal Area of Semarang City," J. Coast. Dev., vol. 16, no. 1, pp. 89-93, 2013.

[7] K. Kathiresan and B. L. Bingham, "Biology of mangroves and mangrove ecosystems," Adv. Mar. Biol., vol. 40, pp. 81-251, 2001. 